\title{
Event Meaning of Vital Way of Personality
}

\section{Подійний зміст життєвого шляху особистості}

\author{
Inesa Hulias \\ Ph.D. in Psychology, \\ Assistant Professor \\ Інеса Гуляс \\ кандидат психологічних \\ наук, доцент \\ E-mail:inehulias@ukr.net \\ orcid.org/0000-0002-4960-4011 \\ Researcher ID: D-9155-2016 \\ Chernivetskyi National \\ Yurii Fedkovych University, \\ Chernivtsi, Ukraine \\ 2, Kotsiubynskoho street, \\ Chernivtsi, Chernivetskyi \\ region, 58012 \\ Чернівецький національний \\ університет ілені Юрія \\ Федьковича, м. Чернівиі, \\ Україна \\ вул. Коцюбинського, 2, \\ м. Чернівці, Чернівецька \\ обл., 58012 \\ Original manuscript received December 14, 2018 \\ Revised manuscript accepted January 20, 2019
}

\section{ABSTRACT}

In the article modern researches on the problems of vital way of personality are considered by domestic scientists. The concept of "event» is proved. It is noted that among the determinations of events there is not a single "classic" one in a kind complication of fixing essence of this phenomenon. The material points of event are formulated: 1) an event is always a certain change; 2) an event is actual, real, it takes place in set time and space, it has limits. It is always a certain chronotop; 3) an event is caused by a personality's metaposition; 4) an event and sense is correlated; 5) an event is multidiamentional; 6) an event is potentially dialogic; 7) an event is always the original «indicator» of vital meaningfulness, personality values and senses.

In order to research the features of event meaning of vital way of personality the method of "Causometry" is used. It is described, that unlike the 
traditional biographic methods, directed only on retrospective description of events which took place in life, the purpose of this technique consists in diagnostics of integral subjective picture of vital way, comprising past and future, expected and planned events. The experience of causometry application in psychotherapy, counseling practice, judicial and psychological expertise, in the decision of lists of tasks on clinical, legal psychology, psychology of personality and vital way, testifies to its positive potential.

271 respondent took part in the research (among them - 99 students of speciality "Primary education", 87 teachers of primary classes at the age of 35-40 years and 85 teachers - at the age of 55-60 years old of Chernivtsi and Chernivtsi region). The questioning was conducted on the base of Yuriy Fedkovych Chernivtsi National University and the Institute of postgraduate pedagogical education of Chernivtsi region. It is revealed that according to the general distribution of three major events of life of respondents on vital spheres there are: at students - "work / studies» (39.4\%), "family and everyday life» (37.37\%), "values» (19.53\%); at teachers at the age of 35-40 years"family and everyday life» (66.67\%), "work / studies» (24.53\%), with a big break "values» (6.92\%); at teachers at the age of 55-60 years - the events of two spheres - "family and everyday life» (69.84\%), "work / studies» (26.98\%). In the distribution of three the least important events of life by vital spheres among students prevail «work / studies» (52.86\%), "values» (17.85\%), "family and everyday life» (17.51\%); among middle-aged teachers - "work / studies» (58.49\%), "family and everyday life» (20.13\%), "values» (10.06\%); among representatives of pre-pension age - «work / studies» (46.03\%), "family and everyday life» (38.1\%).

Key words: vital way, event, causometry, personality.

\section{Вступ}

Категорія життєвого шляху в психології є однією з полівимірних. Актуальність вивчення означеного феномену можна окреслити такими ключовими положеннями: термін «життевий шлях» особистості у низці психологічних концепцій є інтегруючим поняттям, за допомогою якого можна узгодити та систематизувати ряд явищ індивідуального розвитку людини. У зв'язку з цим у сучасній психології приділяють особливу увагу складовим життєвого шляху (життєві й психологічні ситуації, проблеми та кризи, психологічний час особистості, проектування життєвого шля- 
ху, методи і техніки життєдіяльності, вчинок тощо), що становлять певну поняттєву систему та мали б узгоджуватися між собою; специфічною умовою, за якої наразі відбувається дослідження проблем життєвого шляху особистості, є ситуація суспільної кризи (і не тільки), під час якої загострюються всі життєві та сутнісні проблеми індивіда, що вимагає від особистості рефлексії своїх вчинків і поведінки, інтенцій і нахилів, а також планування своєї поведінки у найближчій і віддаленій перспективах, узгодження своїх життєвих планів і задумів із власними можливостями та суспільними умовами; переважна більшість психологів на емпіричному рівні оперують поняттями життєвого шляху, оскільки саме останні є адекватними змісту й результатам психокорекційної та психотерапевтичної практики (Підласа, 2005: 3).

Проблема життєвого шляху привертала увагу низки як вітчизняних, так і зарубіжних учених, зокрема закцентовано на: структурі й «одиницях» життєвого шляху - вікові кризи (Е. Еріксон, 2002; С. Кузікова, 2016; Т. Титаренко, 2003), події (Б. Г. Ананьєв, 1974) тощо; цілісності життєвого шляху (Б. Г. Ананьєв, 1974; С. І. Головаха, 2008; В. Г. Панок \& Г. В. Рудь, 2006); об’єктах спрямування дослідницької уваги під час вивчення життєвого шляху життєва спрямованість, життєвий досвід (Б. Г. Ананьєв, 1974); аспектах самоздійснення (Ш. Бюлер, 1959), самодетермінації (Р. М. Райан \& Е. Л. Десі, 2000; Е. Л. Десі \& Р. М. Райан, 2008), життєтворчої активності особистості (В. М. Ямницький, 2005), життєвих цілей (К. Менсфілд, 2010), життєвих стратегій (Р. Крід, 2011), життєтворенні особистості (Т. М. Титаренко, 2016), проектуванні життєвого шляху (О. М. Гріньова, 2018) тощо.

В окресленому нами форматі проблематики життєвого шляху особистості зупинимося на окремих дослідженнях вітчизняних науковців.

Так, I. А. Підласа (Підласа, 2005) у результаті проведеного емпіричного дослідження життєвих планів і пер- 
спектив студентів виявила їх прогнози щодо матеріальних і соціальних досягнень і видів діяльності після закінчення закладу вищої освіти. Аналіз результатів дослідження засвідчив, що студентам притаманні соціальна зрілість і розкутість, детерміновані, ймовірно, загальним цілісним баченням ними власного життя, реалістичним осмисленням життєвого шляху . Водночас студенти, заохочені соціальними успіхами, прагнуть нових досягнень у майбутньому, що зумовлено їх досить реалістичним, цілісним, об'єктивним сприйманням життя із закономірними на цьому шляху помилками, невдачами, фрустраціями, втратами.

В. Р. Олексюк (Олексюк, 2009) у процесі свого дослідження 3'ясувала, що варіювання модальності, інтенсивності та стабільності показників критеріїв, що визначають процес усвідомлення власного життєвого шляху молодшими школярами, відображається у певному типі життєвої позиції - збалансованому, амбівалентному, конформному, індивідуалістичному - полівимірній системі світоглядних уявлень, оцінок, ціннісних ставлень і самоставлення дитини, на підставі якої здійснюється регуляція власної поведінки та діяльності у різних сферах особистісного буття. Авторка зазначає, що становлення у молодших школярів суб'єктивної картини життєвого шляху характеризується гендерними відмінностями у проектуванні життєвих цілей: хлопчики переважно спрямовані на індивідуальні досягнення, дівчатка - на допомогу іншим, піклування; у виробленні особистісної програми розвитку: перші, зазвичай, апелюють до зростання сили, кмітливості, розуму, інші орієнтовані на потенціювання доброти, працьовитості, відповідальності.

В. Г. Панок і Г. В. Рудь (Панок \& Рудь, 2006) презентували монографію, присвячену дослідженню психологічних аспектів життєвого шляху особистості, 屰 минулого, теперішнього та майбутнього. Автори подають результати власних досліджень щодо особливостей життєвого плану- 
вання старшокласниками та студентами. Особливо цікавими для молоді є вправи та практичні заняття з розвитку життєвого планування.

У руслі розглядуваного доробку українських учених є досить цікавим внесок В. М. Ямницького (Ямницький, 2005). Автор обгрунтував новий психологічний напрям наукову проблему життєтворчості особистості, запропонував її технологічне розв' язання.

Під керівництвом відомої вітчизняної дослідниці Т. М. Титаренко колективом лабораторії соціальної психології особистості Інституту соціальної та політичної психології підготовлено монографію «Психологія життєтворення особистості в сучасному світі» (2016), центром уваги якої є проблема соціально-психологічних практик, використовуваних особистістю для творчої розбудови власного житТя.

Серед останніх дисертаційних праць, присвячених проблемі життєвого шляху особистості, зокрема його проектуванню, варто відзначити роботу О. М. Гріньової (Гріньова, 2018), де презентовано результати теоретико-експериментального дослідження проектування особистістю життєвого шляху в юності. Авторка дослідила психологічні особливості й динаміку становлення смисложиттєвих орієнтацій, ліній життєвого проекту, метапроектування, а також механізмів досліджуваного утворення; встановила низку закономірностей розвитку проектування особистістю життєвого шляху в юності; презентувала зміст, основні етапи, методи й технології розробленої системи психологічних засобів з оптимізації проектування юнаками життєвого шляху.

Незважаючи на масив наявних досліджень у розглядуваній царині, на нашу думку, простежується невелика кількість робіт, які б охоплювали цілісну картину проектування життєвого шляху представників різних вікових категорій. 
Мета статті - теоретично обгрунтувати концепт «подія», емпірично дослідити подійний зміст життєвого шляху особистості.

\section{Завдання статті}

1. Ознайомити читача з низкою вагомих вітчизняних досліджень життєвого шляху особистості.

2. Теоретично обгрунтувати концепт «подія» у контексті життєвого шляху особистості.

3. Емпірично дослідити особливості подійного змісту життєвого шляху особистості.

\section{Методи та методики дослідження}

У роботі використано систему методів наукового пошуку: теоретичних - теоретико-методологічний аналіз, осмислення й узагальнення психологічної науково-методичної літератури з досліджуваної проблеми; емпіричних - опитування, тестування, біографічний метод; математичних.

Для емпіричного вивчення власне життєвого шляху та подійного змісту життєвого шляху особистості застосовано методику «Каузометрія» С. І. Головахи, О. О. Кроніка (Головаха \& Кронік, 2008: 75-101).

Як зауважує В. А. Климчук (Климчук, 2010: 114), проблемою переважної більшості методик дослідження життєвого шляху є відсутність чіткого алгоритму обробки результатів, який би уможливлював виведення узагальнюючих показників, візуалізацію даних, віддзеркалення їх у зручному для розуміння вигляді. Нечіткість процедур аналізу й інтерпретацій результатів провокує ризик суб'єктивності, в тому числі - вплив на результати аналізу власного життєвого шляху дослідника. Каузометрія є однією 3 методик, застосування якої дає змогу досліднику уникнути таких проблем.

Каузометрію відносять до класу біографічних методів, що мають давні традиції в історії психологічної науки (Бур- 
лачук, 1999: 260). Ш. Бюлер, автор однієї з перших концепцій життєвого шляху, пропонувала вивчати життєвий шлях особистості за допомогою біографічного методу (Карпинский, 2002: 87-93). На її переконання, життєвий шлях особистості необхідно розглядати у зв'язку з об'єктивними умовами життя, зі зміною цінностей і всього внутрішнього світу людини. Динаміка існування і функціонування життєвого шляху, за Ш. Бюлер, обумовлена прагненням особистості до самоздійснення. Останнє є об'єктивацією особистості в масштабі життя, а його результатом - 㣙 реалізованість.

Однак, на відміну від традиційних біографічних методів, спрямованих лише на ретроспективний опис подій, що відбулися у житті, мета цієї техніки полягає у діагностиці цілісної суб'єктивної картини життєвого шляху, яка охоплює як минулі, так і майбутні, очікувані та заплановані людиною події.

Зазначимо, що в лютому 2008 р. в Києві в Інституті соціології Національної академії наук України за участі провідних психологів, соціологів, філософів з України, Росії, Латвії, США відбулася Міжнародна наукова конференція «Каузометрія у дослідженнях психологічного часу і життєвого шляху особистості: минуле, теперішнє, майбутнє» (Ахмеров, 2008: 119-122), присвячена 25-річчю каузометричного методу. Мета конференції полягала в організації діалогу між розробниками методу, його користувачами та фахівцями, які лише починають цікавитися каузометрією. На секційних засіданнях виступили 37 доповідачів, продемонстровано три фільми з тематики конференції, проведено майстерню самопізнання за допомогою комп'ютерної каузометрії.

Науковці коротко окреслили історію створення і розвитку каузометричного методу, який розроблено в 19801982 рр. молодими вченими з м. Києва Є. І. Головахою та О. О. Кроніком (Головаха \& Кроник, 1982). Метод каузометрії дозволив операціоналізувати введене Б. Г. Ананьєвим 
(Ананьев, 1974) поняття «суб’єктивна картина життєвого шляху особистості», яке вчений розглядав як важливу характеристику самосвідомості людини. Суб’єктивна картина життєвого шляху особистості завжди розгорнута в часі, фіксує в біографо-історичних датах головні події життєвого шляху, пов' язуючи в єдину систему відліку біологічний, психологічний та історичний час.

На думку Р. А. Ахмерова (Ахмеров, 2008), каузометричний метод дає змогу формувати в людині суб'єктне (самодетермінуюче, відповідальне тощо) ставлення до власного життя. Каузометричний підхід у психології життєвого шляху дає людині ефективну психологічну техніку аналізу та проектування різних варіантів свого життя, допомагає прийняти відповідальне, обдумане рішення. Досвід застосування каузометрії у психотерапії, консультативній практиці, судово-психологічній експертизі, у розв'язанні низки завдань клінічної, юридичної психології, психологї̈ особистості та життєвого шляху свідчить про її позитивний потенціал.

\section{Результати та дискусії}

Подійний підхід до життєвого шляху наразі є значущим у психології особистості та складає необхідний вимір досліджень індивідуального життя в психологічній науці. Показовим є те, що проблему впливу ранніх подій на долю людини вивчав ще З. Фрейд (Хьелл, 2005). У 20-30-х роках минулого століття проведено масштабні дослідження (Эриксон, 2002), у межах яких здійснено спроби встановити певні закономірності подійного аспекту життєвого шляху особистості, виявити взаємозв' язки між «зовнішніми» $\mathrm{i}$ «внутрішніми» подіями.

У радянській психології основи для розуміння категорії події у контексті психології особистості заклав Б. Г. Ананьєв (Ананьев, 1974), який увів поняття «суб’єктивна картина життєвого шляху». Вчений визначав її як відображення у свідомості особистості її життєвого шляху в часі та запро- 
понував його (життєвого шляху) періодизацію, розглядаючи при цьому об'єктивну подійність (конкретно-історичні події й умови розвитку індивіда) і подійність внутрішню: індивідуальні біографічні події, що вбудовувалися у межі більш загальної хронології: життєвого «старту», «кульмінацій» і «фінішу» особистості на їі життєвому шляху (Анцыферова, 2004; Логинова, 2001). Б. Г. Ананьєв (Ананьев, 1974) і його учениця Н. А. Логінова (Логинова, 2001) заклали основу типології життєвих подій, припускаючи, що саме вони формують специфічну структуру життєвого шляху особистості. Подійний підхід також яскраво представлено в київській школі психології життєвого шляху (Кроник, 2008). Проте, на переконання Г. Б. Паукової (Паукова, 2011: 144), власне концепт події тут ще достатньо повно не розроблено, оскільки увагу дослідників сфокусовано на дослідженні подійної насиченості життєвого шляху, міжподійних зв'язків - словом, того, що відбувається між подіями, а не всередині них. Загалом можна сказати, що у форматі подійного підходу подія певною мірою «відривається» від особистості, вона «стається» 3 нею, тоді як активність особистості у творенні подій свого життя залишається поза увагою.

Дещо в іншому плані перебуває проблема події у межaх суб’єктного підходу (Абульханова, 2001; Рубинштейн, 1997). У працях дослідників ставляться питання про активність особистості щодо свого життя, ініціювання і керування його подіями. Особистість розуміють як суб’єкт, який не пасивно підкорюється тому, що стається з ним, а вибудовує траєкторію свого життя на перетині світу зовнішніх обставин, умов, впливів і вимог і світу внутрішніх бажань, прагнень, переживань тощо.

Загалом, подія є певним моментом часу та простору, де життя набуває можливості зустрітися із самим собою, «точка біфуркації», що позначає момент нестійкості, невизначеності та закладає основи задля нового повороту життєвого сюжету. Синтезуючи існуючі визначення подій - серед 
яких, зауважимо, немає жодного «класичного» $з$ причини складності фіксації суті цього феномену, - сформулюємо низку положень, що передають окремі суттєві моменти подійності.

1. Подією завжди є певна зміна. Щось стається, зупиняється, приходить у рух. Подія - це точка, яка ділить неперервну континуальність життєвого часу на те, що було до події, і те, що стало після неї. Фіксується момент переходу .

2. Подія фактична, реальна, вона відбувається у певному часі та просторі, має межі. Вона завжди є певним хронотопом.

3. Подія задається метапозицією особистості. Задля того, щоб побачити, розрізнити у тканині свого життя певну подію, особистість повинна перебувати на певній дистанції від неї, проявити ставлення до неї, в іншому випадку вона залишиться просто ситуацією, «розставлянням сил» у певний момент часу та простору. Вона повинна мати певну завершеність.

4. Оскільки подія створюється на перетині внутрішнього світу особистості (світу психічного) і зовнішнього світу, то форма її визначається завжди в координатах того, хто спостерігає, переживає, ініціює подію. Ідеться про взаємозв'язок категорій події і смислу (Кондаков, 2000; Розин, 2000; Сайко, 2000). По суті, подія - це сенс, імплікований у дійсність чи розпізнаний, знайдений у ній.

5. Подія полівилірна. Можна говорити про те, що ii структура організована за принципом фракталу. Одиничний атомарний факт лише «зародок» події у внутрішньому житті особистості, що набуває згодом асоціативних зв'язків з іншими життєвими подіями, обростає смислами, вбудовується у контекст життєвих відношень.

6. Подія потенційно діалогічна. Вона задається не лише життєвим контекстом особистості, яка переживає їі, але й життєвими контекстами інших людей (Старовойтенко, 2010), зокрема і значущих інших, представлених у внут- 
рішньому світі особистості, - й такі контексти можуть бути розгорнутими.

7. Подія завжди є своєрідним «індикатором» життєвих значущостей, особистісних иінностей і слислів.

Кожна людина, звертаючись до себе, може відновити у пам'яті певні події, які вирішально вплинули на її життя (водночас як інші залишилися непомітними). Такі події вбудовуються в уже існуючі у неї смислові координати, асимілюються тканиною індивідуального життя, беруть участь у процесі формування світогляду особистості. По суті, подія - це і є життя, проте іноді це особливо «опуклий», яскравий, видатний іiі момент, у якому можуть «спресовуватися» основні життєві теми. Саме за рахунок високої щільності, напруження «всередині» події вона може «підривати» індивідуальне життя, відкривати нове русло його течії. У цьому контексті О. Б. Старовойтенко зазначає: «У моментах «подій» відбуваються сплески відношень, коли особиста, внутрішня цінність того, що відбувається, може визначати унікальні дії та вчинки людини, важливі за межами індивідуального життя» (Старовойтенко, 2010: 3-18).

На переконання Т. М. Титаренко (Титаренко, 2003: 95), життєва подія, конкретний вчинок є вирішальними для розгортання життєвого шляху. В межах постнекласичної парадигми, зазначає дослідниця (Титаренко, 2009: 88), життєвий шлях є низкою подій, між якими складається не завжди явний, неієрархічний зв'язок. Конструювання, осмислення власного шляху - це пошук неперервності й панорамності у цій низці дискретних подій, намагання надати ризомним міжподієвим зв'язкам хоча б часткового причинно-цільового характеру.

Подія - завжди значуща для особистості, людина запам’ятовує їі на тривалий час. Подія вносить суттєві зміни в буденний плин життя. Масштаб події визначається її впливом на основні сфери життєдіяльності, а саме: на продук- 
тивність праці, стан здоров'я, взаємини в побуті, родині, на роботі, ставлення до себе, зовнішні умови життя тощо. Одні й ті ж самі зовнішні події відіграють зовсім різну роль у житті різних людей. I це зрозуміло, адже в життєвому світі кожного зовнішня подія набуває різної забарвленості, різної ціннісної валентності, стає власною, інакшою, особливою (Титаренко, 2003: 95).

Отже, за Б. Г. Ананьєвим (Ананьев, 1974), основною одиницею і найпростішим елементом життєвого шляху є подія. Загалом, під життєвою подією розуміють «поворотний етап життєвого шляху людини, пов'язаний із прийняттям нею на тривалий період їі життя важливих рішень» (Рубинштейн, 2002). У контексті останнього нещодавно захищено дисертацію на здобуття наукового ступеня доктора психологічних наук «Психологія прийняття життєвих рішень особистістю» (Санніков, 2016), де на засадах системно-особистісного підходу представлено авторську концепцію прийняття життєвих рішень особистістю. О. I. Санніков (Санніков, 2016: 39) розкрив обсяг і зміст феномену, що характеризує це явище як психологічну систему складових, організація і взаємодія яких відображає цілісність особистості та спрямовує її активність на здійснення вибору з альтернативно можливих варіантів; обгрунтував компоненти психологічної структурно-функціональної системи прийняття життєвого рішення особистістю, що презентовані специфічними характеристиками: блоком особистісних компонентів, блоком компонентів взаємодії із середовищем, блоком компонентів рішучості; визначив етапи трансформації означеної системи (сприйняття ситуації, пошук варіантів, їх аналіз, вибір, реалізація й оцінка продуктивності вибору); схарактеризував механізми активації особистісних ресурсів, критерії та форми здійснення життєвого вибору; визначив ресурси та предиктори прийняття життєвих рішень особистості, механізми вольової, емоційної, когнітивної та мотиваційної регуляції прийняття особистістю життєвих рішень; навів результа- 
ти диференціально-психологічного аналізу, спрямованого на пошук широкого кола психологічних властивостей особистості, що різняться за рівнем проявів вольових якостей, упевненістю в собі, емоційною диспозицією, тривожністю, емоційним інтелектом, мотивацією досягнень.

Наше дослідження є продовженням вивчення особливостей життєвого шляху особистості у контексті попередніх розвідок за методикою «Каузометрія» .

Процедуру опитування проводили в індивідуальній формі тривалістю від 40 до 60 хв за етапами: біографічної розминки; формування списку подій; їх датування; емоційної оцінки подій; рангування останніх за значущістю «для себе»; причинного аналізу міжподійних зв'язків; цільового аналізу міжподійних відношень; позначення сфер належності подій; виявлення психологічного віку.

У дослідженні взяв участь 271 респондент (із них - 99 студентів спеціальності «Початкова освіта», 87 учителів початкових класів віком $35-40$ років і 85 - віком 55-60 років із м. Чернівці та Чернівецької області). Опитування проводили на базі Чернівецького національного університету імені Юрія Федьковича й Інституту післядипломної педагогічної освіти Чернівецької області. Обробку результатів здійснювали шляхом підрахунку відсотків.

За загальним розподілом трьох найважливіших подій життя респондентів за життєвими сферами отримано такі результати.

Студенти - майбутні педагоги більшою мірою виокремлюють три найважливіші події життя за сферами «робота / навчання» $(39,4 \%)$, «сім'я і побут» $(37,37 \%)$, «цінності» $(19,53 \%)$. Слабко виражено сфери «дозвілля» $\mathrm{i}$ «здоров'я» - 2,02\% і 1,68 \% відповідно. Поза увагою молодих людей залишилися аспекти «суспільство» і «природа», що не знайшли відсоткового вираження.

У вчителів вікол 35-40 років три найбільш значущі події життя домінують у сферах «сім'я і побут» $(66,67 \%)$, «робота / навчання» $(24,53 \%)$, з великим відривом - «цін- 
ності» (6,92\%). Сфрери «здоров'я» і «дозвілля» відзначено низькими показниками - 1,26\% і 0,62\% відповідно; події сфер «суспільство» $\mathrm{i}$ «природа» як такі серед найбільш значущих не виявлено.

У педагогів вікол 55-60 років серед найголовніших подій життя превалюють події двох сфер - «сім'я і побут» $(69,84 \%)$, помітно менше - «робота / навчання» $(26,98 \%)$. Слабко виражено сферу «цінності» $(3,17 \%)$, маркування інших сфер відсутнє.

Розподіл опитаними 15-ти найважливіших подій життя за емоційним забарвленням має таку картину: в студентів, порівняно з педагогами середнього та старшого віку, позитивних подій найменше $(81,89 \%$; 90,69\% і 87,3\% відповідно), нейтральних - дещо більше, ніж в інших груп вибірки $(2,96 \% ; 2,01 \%$ і $2,54 \%$ відповідно), негативних найбільше $(15,15 \% ; 7,3 \%$ і 10,16\% відповідно).

У розподілі трьох найленш важливих подій життя за життєвими сферами у студентів переважають сфери «робота / навчання» $(52,86 \%)$, «цінності» $(17,85 \%)$, «сім'я і побут» $(17,51 \%)$. При цьому мінімально виражені «дозвілля» $(7,41 \%)$, «здоров'я» $(3,7 \%)$, «суспільство» $(0,67 \%)$; «природа» - не виражено.

У вчителів середнього віку при розподілі трьох найменш важливих подій життя за життєвими сферами найактуальнішими є сфрери: «робота / навчання» $(58,49 \%)$, «сім'я і побут» $(20,13 \%)$, дещо менше - «цінності» $(10,06 \%)$. Незначні показники представлено за сферами «дозвілля» $(8,81 \%)$ i «здоров'я» $(2,51 \%)$; вираження сфрер «природа» $\mathrm{i}$ «суспільство» немає.

Представники передпенсійного віку в цьому плані закцентувалися переважно на сферах «робота / навчання» $(46,03 \%)$, «сім'я і побут» $(38,1 \%)$. Мінімально вираженими є сфрери «цінності», «дозвілля» (по 6,35\% відповідно) та «здоров'я» $(3,17 \%)$. Сфери «суспільство» і «природа» - не мають свого відображення. 


\section{Висновки}

На основі проведених теоретичного й емпіричного досліджень анонсованої теми наразі можна зробити такі висновки: 1) як категорію психології життєвий шлях розглядають у якості фундаментального системного полівимірного поняття, що передбачає розкриття індивідуальної історії людини, сукупність подій та обставин індивідуального розвитку особистості; 2) життєві події можуть бути тими елементарними утвореннями, з яких складається життєвий шлях і які відбуваються внаслідок складної взаємодії біологічних, психологічних і соціальних чинників, що значною мірою визначають такі важливі характеристики, як час, послідовність і спосіб реалізації життєвих подій i вчинків (за В. А. Роменцем); 3) проведене емпіричне дослідження засвідчило такі результати загального розподілу трьох найважливіших подій життя респондентів за життєвими сферами: у студентів - «робота / навчання» $(39,4 \%)$, «сім'я і побут» $(37,37 \%)$, «цінності» $(19,53 \%)$; у вчителів вікол 35-40 років - «сім'я і побут» $(66,67 \%)$, «робота / навчання» $(24,53 \%)$, з великим відривом - «цінності» $(6,92 \%)$; у педагогів вікол 55-60 років - превалюють події двох сфер - «сім'я і побут» $(69,84 \%)$, помітно менше - «робота / навчання» $(26,98 \%)$. У розподілі трьох найленш важливих подій життя за життєвими сферами у студентів переважають сфери «робота / навчання» $(52,86 \%)$, «цінності» $(17,85 \%)$, «сім'я і побут» $(17,51 \%) ;$ у вчителів середнього віку - «робота / навчання» $(58,49 \%)$, «сім'я і побут» $(20,13 \%)$, дещо менше - «цінності» $(10,06 \%) ;$ у представників передпенсійного віку - «робота / навчання» $(46,03 \%)$, «сім'я і побут» $(38,1 \%)$.

Перспективи подальших досліджень убачаємо у вивченні особливостей майбутніх подій (найбільш і найменш важливих) життя респондентів означених категорій, їх індивідуально-психологічних властивостей у формуванні життєвої перспективи. 


\section{Література}

Абульханова К. А., Березина Т. Н. Время личности и время жизни. Санкт-Петербург : Алетейя, 2001. 304 с.

Ананьев Б. Г. К психофизиологии студенческого возраста. Совреленные психолого-педагогические проблелы высшей школы. Ленинград : ЛГУ, 1974. С. 3-15.

Анцыферова Л. И. Развитие личности и проблемы геронтопсихологии. Москва : Издательство «Институт психологии РАН», 2004. 415 с.

Ахмеров Р. А. Международная научная конференция «Каузометрия в исследованиях психологического времени и жизненного пути личности: прошлое, настоящее, будущее». Психологический журнал. 2008. Т. 29. № 5. С. 119-122.

Бурлачук Л. Ф., Морозов С. М. Словарь-справочник по психодиагностике. Санкт-Петербург : Питер-Ком, 1999. 528 с.

Гріньова О. М. Психологія проектування життєвого шляху особистості юнацького віку: автореф. дис. ... д-ра психол. наук: 19.00.07. Київ, 2018. 44 с.

Головаха Е. И., Кроник А. А. К исследованию мотивации жизненного пути личности: техника «каузометрии». Мотиваиия личности. М. : НИИ общ. педагогики АПН СССР, 1982. С. 99-108.

Головаха Е. И., Кроник А. А. Психологическое время личности. М. : Смысл, 2008. 267 с.

Карпинский К. В. Психология жизненного пути личности. Гродно : ГрГУ, 2002. 167 с.

Климчук В. А. Моделирование жизненного пути с помощью каузометрии, многомерного шкалирования и кластерного анализа. Вопросы психологии. 2010. № 3. С. 113-120.

Кондаков И. В. Архитектоника события. Мир психологии. 2000. № 4. С. $38-50$.

Кроник А. А., Ахмеров Р. А. Каузометрия: методы самопознания, психодиагностики и психотерапии в психологии жизненного пути. Москва : Смысл, 2008. 294 с.

Кузікова С. Model of psychological correction of crisis of adolescence. Психологія особистості. 2016. № 1. C. 24-33. DOI 10.15330/ ps.7.1.24-33.

Логинова Н. А. Психобиографический метод исследования и коррекции личности. Алматы : Казак университеті, 2001. 172 с.

Олексюк В. Р. Особливості усвідомлення молодшими школярами власного життєвого шляху: автореф. дис. ... канд. психол. наук: 19.00.07. Івано-Франківськ, 2009. 20 с.

Панок В. Г., Рудь Г. В. Психологія життєвого шляху особистості: монографія. Київ : Ніка-Центр, 2006. 280 с.

Паукова А. Б. Динамика отношения к жизни в результате рефлексии жизненных событий. Мир психологии. 2011. № 4. С. 143-150. 
Підласа І. А. Психологічний аналіз категорії життєвого шляху особистості: автореф. дис. ... канд. психол. наук: 19.00.01. Київ, 2005. $24 \mathrm{c}$.

Психологія життєтворення особистості в сучасному світі: монографія / Ю. Д. Гундертайло, В. О. Климчук, О. Я. Кляпець та ін.; за ред. T. М. Титаренко; Національна академія педагогічних наук України, Інститут соціальної та політичної психології. Київ : Міленіум, 2016. 320 c.

Розин В. М. Что такое событие? (Анализ условий событийного дискурса). Мир психологии. 2000. № 4. С. 31-38.

Рубинштейн С. Л. Основы общей психологии. Санкт-Петербург : Питер, 2002. $720 \mathrm{c.}$

Рубинштейн С. Л. Человек и мир. Москва : Наука, 1997. 191 с.

Сайко Э. В. Событийная жизнь человека в его со-бытии. Мир психологиu. 2000. № 4. С. 38-50.

Санніков О. І. Психологія прийняття життєвих рішень особистістю: автореф. дис. ... д-ра психол. наук: 19.00.01. Одеса, 2016. 43 с.

Санников А. И. Психология принятия жизненных решений личностью: дис. ... д-ра психол. наук: 19.00.01. Одесса, 2016. 508 с.

Старовойтенко Е. Б. Парадигма жизни в персонологии. Психология: журн. Высш. шк. эконолики. 2010. Т. 7. № 1. С. 3-18.

Титаренко Т. М. ЖКиттєвий світ особистості: у межах і за межами буденності. Київ : Либідь, 2003. 376 с.

Титаренко Т. М. Постмодерні концептуалізації понять «особистість» та «життєвий шлях». Психологія і суспільство. 2009. № 4. С. 83-95.

Хьелл Л., Зиглер Д. Теории личности. Санкт-Петербург : Питер, 2005. $607 \mathrm{c.}$

Эриксон Э. Детство и общество. Санкт-Петербург : Речь, 2002. 416 с.

Ямницький В. М. Психологічні чинники розвитку життєтворчої активності особистості в дорослому віці: автореф. дис. ... д-ра психол. наук: 19.00.07. Київ, 2005. 39 с.

Buhler, Ch. (1959). Theoretical Observations about Life's Basic Tendencies. American Journal of Psychotherapy, 3, Vol. 13, 561-581.

Creed, P., Tilbury, C., Buys, N., \& Crawford, M. (2011). Cross-lagged relationships between career aspirations and goal orientation in early adolescents. Journal of vocational behavior, 1, Vol. 78, 92-99. Retrieved from https://doi.org/10.1016/j.jvb.2010.09.010.

Deci, E. L., \& Rayan, R. M. Self-Determination Theory: A Macrotheory of Human Motivation, Development and Health. Canadian psychology, 3, Vol. 49, 182-185. Retrieved from https://dx.doi.org/10.1037/ a0012801.

Kuzikova, S. (2016). Model of psychological correction of crisis of adolescence. Психологія особистості, 1, 24-33. Retrieved from https:// doi:10.15330/ps.7.1.24-33. 
Mansfield, C. F. (2010). Motivating adolescents: Goals for Australian students in secondary schools. Australian Journal of Educational \& Developmental Psychology, 10, 44-55.

Ryan, R. M., \& Deci, E. L. (2000). Intrinsic and extrinsic motivations: classic definitions and new directions. Contemporary educational psychology, 25, 54-67. Retrieved from https://doi.org/10.1006/ ceps.1999.1020.

\section{References}

Abul'hanova, K. A., \& Berezina, T. N. (2001). Vremja lichnosti i vremja zhizni [Time of personality and time of life]. Sankt-Peterburg : Aleteja [in Russian].

Anan'ev, B. G. (1974). K psihofiziologii studencheskoho vozrasta [To the psychophysiology of student age]. Sovremennye psihologo-pedagogicheskie problemy vysshej shkoly - Modern psychological and pedagogical problems of higher school (pp. 3-15). Leningrad : LGU [in Russian].

Ancyferova, L. I. (2004). Razvitie lichnosti i problemy gerontopsihologii [Development of personality and problems of gerontopsychology]. Moskva : Izdatel'stvo «Institut psihologii RAN» [in Russian].

Ahmerov, R. A. (2008). Mezhdunarodnaja nauchnaja konferencija «Kauzometrija $\mathrm{v}$ issledovanijah psihologicheskogo vremeni i zhiznennogo puti lichnosti: proshloe, nastojashchee, budushchee» [An international scientific conference of «Causometry in the researches of psychological time and vital way of personality: the past, present, and future»]. Psihologicheskij zhurnal - Psychological journal, 5, 119122 [in Russian].

Burlachuk, L. F., \& Morozov, S. M. (1999). Slovar'-spravochnik po psihodiagnostike [Reference dictionary-book on a psychodiagnosis]. SanktPeterburg : Piter-Kom [in Russian].

Hrinova, O. M. (2018). Psykholohiia proektuvannia zhyttievoho shliakhu osobystosti yunatskoho viku [Psychology of planning of vital way of personality of youth age]. Extended abstract of Doctor's thesis. Kyiv [in Ukrainian].

Golovaha, E. I., \& Kronik, A. A. (1982). K issledovaniju motivacii zhiznennogo puti lichnosti: tehnika «kauzometrii» [To study the motivation of the person's life path: the technique of «causometry»]. Motivacija lichnosti-Personality motivation (pp. 99-108). Moskva : NII obshch. pedagogiki APN SSSR [in Russian].

Golovaha, E. I., \& Kronik, A. A. (2008). Psihologicheskoe vremja lichnosti [Psychological time of personality]. Moskva : Smysl [in Russian].

Karpinskij, K. V. (2002). Psihologija zhiznennogo puti lichnosti [Psychology of vital way of personality]. Grodno : GrGU [in Belarusian]. 
Klimchuk, V. A. (2010). Modelirovanie zhiznennogo puti s pomoshch'ju kauzometrii, mnogomernogo shkalirovanija i klasternogo analiza [The design of vital way by causometry, multidimensional scaling and cluster analysis]. Voprosy psihologii-Questions on psychology, 3, 113-120 [in Russian].

Kondakov, I. V. (2000). Arhitektonika sobytija [Architectonics of event]. Mir psihologii - World of psychology, 4, 38-50 [in Russian].

Kronik, A. A., \& Ahmerov, R. A. (2008). Kauzometrija: metody samopoznanija, psihodiagnostiki i psihoterapii $v$ psihologii zhiznennogo puti [Causometry: methods of self-knowledge, psychodiagnostics and psychotherapy in psychology of vital way]. Moskva : Smysl [in Russian].

Kuzikova, S. (2016). Model of psychological correction of crisis of adolescence. Psykholohiia osobystosti - Psychology of personality, 1, 24-33. DOI 10.15330/ps.7.1.24-33 [in Ukrainian].

Loginova, N. A. (2001). Psihobiograficheskij metod issledovanija i korrekcii lichnosti [Psychobiographic method of research and correction of personality]. Almaty : Kazak universiteti [in Kazakstan].

Oleksiuk, V. R. (2009). Osoblyvosti usvidomlennia molodshymy shkoliaramy vlasnoho zhyttievoho shliakhu [Features of junior schoolboys' awareness of own vital way]. Extended abstract of candidate's thesis. Ivano-Frankivsk [in Ukrainian].

Panok, V. H., \& Rud, H. V. (2006). Psykhologiia zhyttievoho shliakhu osobystosti [Psychology of vital way of personality]. Kyiv : Nika-Tsentr [in Ukrainian].

Paukova, A. B. (2011). Dinamika otnoshenija k zhizni v rezul'tate refleksii zhiznennyh sobytij [Dynamics of attitude toward life as a result of reflection of vital events]. Mir psihologii - World of psychology, 4, 143-150 [in Russian].

Pidlasa, I. A. (2005). Psykholohichnyi analiz katehorii zhyttievoho shliakhu osobystosti [Psychological analysis of the category of vital way of personality]. Extended abstract of candidate's thesis. Kyiv [in Ukrainian].

Hundertailo, Yu. D., Klymchuk, V. O., \& Kliapets, O. Ya. (2016). Psykholohiia zhyttietvorennia osobystosti $v$ suchasnomu sviti [Psychology of life way of personality in the modern world]. T. M. Tytarenko (Ed.). Kyiv : Milenium [in Ukrainian].

Rozin, V. M. (2000). Chto takoe sobytie? (Analiz uslovij sobytijnogo diskursa) [What is event? (Analysis of terms of event discourse)]. Mir psihologii - World of psychology, 4, 31-38 [in Russian].

Rubinshtein, S. L. (2002). Osnovy obshchej psihologii [Bases of general psychology]. Sankt-Peterburg : Piter [in Russian].

Rubinshtein, S. L. (1997). Chelovek i mir [Man and world]. Moskva : Nauka [in Russian]. 
Sajko, E. V. (2000). Sobytijnaja zhizn' cheloveka v ego so-bytii [Event life of a man in his co-existing]. Mir psihologii - World of psychology, 4, 38-50 [in Russian].

Sannikov, O. I. (2016). Psykholohiia pryiniattia zhyttievykh rishen osobystistiu [Psychology of taking vital decisions by a personality]. Extended abstract of Doctor's thesis. Odesa [in Ukrainian].

Sannikov, A. I. (2016). Psihologija prinjatija zhiznennyh reshenij lichnost'ju [Psychology of taking vital decisions by a personality]. Doctor's thesis. Odesa [in Russian].

Starovojtenko, E. B. (2010). Paradigma zhizni v personologii [A paradigm of life in the personology]. Psihologiia: zhurn. Vysshej shkoly jekonomiki - Psychology: a Journal of Higher school of Economy, 1, 3-18 [in Russian].

Tytarenko, T. M. (2003). Zhyttievyi svit osobystosti: u mezhakh i za mezhamy budennosti [Vital world of a personality: scope and outside ordinariness ]. Kyiv : Lybid [in Ukrainian].

Tytarenko, T. M. (2009). Postmoderni kontseptualizatsii poniat «osobystist» ta «zhyttievyi shliakh» [Postmodern concepts of "personality» and «vital way»]. Psykholohiia $i$ suspilstvo - Psychology and society, 4, 83-95 [in Ukrainian].

Khiell, L., \& Zigler, D. (2005). Teorii lichnosti [Theories of personality]. Sankt-Peterburg : Piter [in Russian].

Jerikson, Je. (2002). Detstvo i obshchestvo [Childhood and society]. SanktPeterburg : Rech' [in Russian].

Yamnytskyi, V. M. (2005). Psykholohichni chynnyky rozvytku zhyttietvorchoi aktyvnosti osobystosti v doroslomu vitsi [Psychological factors of development of vital creative activity of personality in grown man age]. Extended abstract of Doctor's thesis. Kyiv [in Ukrainian].

Buhler, Ch. (1959). Theoretical Observations about Life's Basic Tendencies. American Journal of Psychotherapy, 3, Vol. 13, 561-581.

Creed, P., Tilbury, C., Buys, N., \& Crawford, M. (2011). Cross-lagged relationships between career aspirations and goal orientation in early adolescents. Journal of vocational behavior, 1, Vol. 78, 92-99. Retrieved from https://doi.org/10.1016/j.jvb.2010.09.010.

Deci, E. L., \& Rayan, R. M. Self-Determination Theory: A Macrotheory of Human Motivation, Development and Health. Canadian psychology, 3, Vol. 49, 182-185. Retrieved from https://dx.doi.org/10.1037/ a0012801.

Mansfield, C. F. (2010). Motivating adolescents : Goals for Australian students in secondary schools. Australian Journal of Educational \& Developmental Psychology, 10, 44-55.

Ryan, R. M., \& Deci, E. L. (2000). Intrinsic and extrinsic motivations: classic definitions and new directions. Contemporary educational 
psychology, 25, 54-67. Retrieved from https://doi.org/10.1006/ ceps.1999.1020.

\section{АНОТАЦІЯ}

У статті розглянуто сучасні дослідження проблем життєвого шляху особистості вітчизняними вченими. Обгрунтовано концепт "подія». Зазначено, що серед існуючих визначень події немає жодного «класичного» з причини складності фіксації суті цього феномену. Сформульовано суттєві моменти подійності: 1) подією завжди є певна зміна; 2) подія фактична, реальна, вона відбувається у певному часі та просторі, має межі. Вона завжди є певним хронотопом; 3) подія задається метапозицією особистості; 4) подія і сенс взаємопов'язані; 5) подія полівимірна; 6) подія потенційно діалогічна; 7) подія завжди є своєрідним «індикатором» життєвих значущостей, особистісних цінностей і смислів.

Із метою дослідження особливостей подійного змісту життєвого шляху особистості використано методику "Каузометрія». Описано, що на відміну від традиційних біографічних методів, спрямованих лише на ретроспективний опис подій, які відбулися у житті, мета цієї техніки полягає у діагностиці цілісної суб'єктивної картини життєвого шляху, що охоплює як минулі, так і майбутні, очікувані та заплановані людиною події. Досвід застосування каузометрії у психотерапії, консультативній практиці, судово-психологічній експертизі, у розв'язанні низки завдань клінічної, юридичної психології, психології особистості та життєвого шляху свідчить про ії позитивний потенціал.

У дослідженні взяв участь 271 респондент (із них - 99 студентів спеціальності «Початкова освіта», 87 учителів початкових класів віком 35-40 років і 85 - віком 55-60 років із м. Чернівці та Чернівецької області). Опитування проводили на базі Чернівецького національного університету імені Юрія Федьковича й Інституту післядипломної педагогічної освіти Чернівецької області. Виявлено, що за загальним розподілом трьом найважливіших подій життя респондентів за життевими срерами є: у студентів - «робота / навчання» (39,4\%), "сім'я і побут» (37,37\%), «цінності» (19,53\%); у вчителів віком 35-40 років - «сім'я і побут» (66,67\%), «робота / навчання» (24,53\%), з великим відривом «цінності» (6,92\%); у педагогів віком 55-60 років - превалюють події двох сфер - «сім'я і побут» (69,84\%), помітно менше - «робота / навчання» (26,98\%). У розподілі трьох найменш важливих подій життя за життєвими срерами у студентів переважають срери «робота / навчання» (52,86\%), «цінності» (17,85\%), "сім'я і побут» (17,51\%); у вчителів середнього віку - "робота / навчання» (58,49\%), “сім'я і побут» 
(20,13\%), дещо менше - «цінності» (10,06\%); у представників передпенсійного віку - «робота / навчання» (46,03\%), «сім'я і побут» (38,1\%).

Ключові слова: життєвий шлях, подія, каузометрія, особистість.

\section{Гуляс Инесса. Событийное содержание жсизненного пути личности}

\section{АННОТАЦИЯ}

В статье рассмотрены современные исследования проблем жизненного пути личности отечественными учеными. Обосновано концепт "событие». Отмечено, что среди существующих определений события нет ни одного "классического» в виду сложности фиксации сути этого феномена. Сформулированы существенные моменты событийности: 1) событием всегда является определенное изменение; 2) событие фактическое, реальное, оно происходит в определенном времени и пространстве, имеет пределы. Оно всегда есть определенным хронотопом; 3) событие задается метапозицией личности; 4) событие и смысл взаимосвязаны; 5) событие многоизмеримо; 6) событие потенциально диалогическое; 7) событие всегда является своеобразным «индикатором» жизненных важностей, личностных ценностей и смыслов.

С целью исследования особенностей событийного содержания жизненного пути личности использована методика "Каузометрия". Описано, что в отличие от традиционных биографических методов, направленных лишь на ретроспективное описание событий, которые состоялись в жизни, цель данной техники заключается в диагностике целостной субъективной картины жизненного пути, которая охватывает как прошлые, так и будущие, ожидаемые и запланированные человеком события. Опыт применения каузометрии в психотерапии, консультативной практике, судебно-психологической экспертизе, в решении ряда заданий клинической, юридической психологии, психологии личности и жизненного пути свидетельствует о ее позитивном потенциале.

В исследовании принял участие 271 респондент (из них- 99 студентов специальности "Начальное образование», 87 учителей начальных классов возрастом 35-40 лет и 85 - возрастом 55-60 лет из г. Черновцы и Черновицкой области). Опросы проводили на базе Черновицкого национального университета имени Юрия Федьковича и Института последипломного педагогического образования Черновицкой области. Обнаружено, что за общим распределением трех важнейших событий 
жизни респондентов за жизненными сферами являются: у студентов - «работа / учеба» (39,4\%), «семья и быт» (37,37\%), «ценности» (19,53\%); у учителей возрастом 35-40 лет - «семья и быт» (66,67\%), "работа / учеба» (24,53\%), с большим отрывом - «ценности» (6,92\%); у педагогов возрастом 55-60 лет - превалируют события двух сфер«семья и быт» (69,84\%), заметно меньше - «работа / учеба» (26,98\%). В распределении трех наименее важных событий жизни за жизненными сферами у студентов преобладают сферы "работа / учеба» (52,86\%), «ценности» (17,85\%), "семья и быт» $(17,51 \%) ;$ у учителей среднего возраста - «работа / учеба» (58,49\%), «семья и быт» $(20,13 \%)$, несколько меньше - «ценности» (10,06\%); у представителей предпенсионного возраста - «работа / учеба» (46,03\%), «семья и быт» (38,1\%).

Ключевые слова: жизненный путь, событие, каузометрия, личHocmb. 